\title{
Call to cancel 2016 Olympics because of Zika risk is not backed by WHO guidance
}

\author{
Rebecca Coombes, head of features and investigations
}

The BMJ

A call by a leading public health expert to cancel this summer's Olympic Games in Brazil for fear of accelerating a global spread of the Zika virus has been quelled by new World Health Organization guidance, which backs travel but advises athletes and visitors to take simple steps to manage health risks.

Writing in the Harvard Public Health Review this month, ${ }^{1}$ Amir Attaran, professor in the faculties of law and medicine at the University of Ottawa in Canada, described Rio de Janeiro as being at the "heart" of the current Zika epidemic and said that the Olympic organisers must confront "the bitter truth: the 2016 Olympic and Paralympic Games must be postponed, moved, or both, as a precautionary concession."

Brazil is at the centre of a large outbreak of Zika affecting 58 countries worldwide. Although the Brazil epidemic began in the north east of the country last year, it has spread to densely populated areas in other regions, including Rio de Janeiro.

In January the International Olympic Committee declared Rio a "safe environment" for the games, but suspected Zika cases in Rio are now the highest of any state in Brazil (26 000), and its Zika incidence rate is the fourth worst (157 per 100000$)$. "In other words," wrote Attaran, "Rio is not on the fringes of the outbreak, but inside its heart." He condemned complacency over the risks to health.

"All it takes is one infected traveler," he wrote. "A few viral introductions of that kind, in a few countries, or maybe continents, would make a full blown global health disaster. Scientists can disagree on how much the mass migration of 500 000 foreigners will accelerate the virus's global spread and make the pandemic worse-but none can possibly argue that it will slow it down or make things better."

Attaran noted the ongoing work to invent new technologies to slow the spread of Zika, including effective vaccine, antiviral drugs, insecticide, or a genetically engineered mosquito. "But by spreading the virus faster and farther, the [Olympic] games steal away the very thing - time - that scientists and public health professionals need to build such defences," he wrote.

Chris Dye, WHO director of strategy, said, "We are aware of the diversity of views that have been expressed about the Olympics." After considering the evidence, WHO had issued advice to people travelling to Rio, ${ }^{4}$ he said.

The WHO statement advised athletes and visitors to practise safe sex, choose air conditioned accommodation, use insect repellent, and wear light coloured clothing that covers as much of the body as possible. Travellers should avoid "impoverished" and "overcrowded" areas in the city, it added. Pregnant women were warned not to travel and were advised to practise safe sex or abstain from sex with partners returning from Zika hit areas during their pregnancy.

Brazil is a big trading hub with 400000 people travelling to and from the country each week, so the Olympics may not, in relative terms, see a dramatic change in traffic between countries. The games will also take place during Brazil's wintertime, when fewer mosquitoes are active and the risk of being bitten is lower. A seasonal drop in dengue and chikungunya is also seen at that time of year.

Attaran A. Off the podium: why public health concerns for global spread of Zika virus means that Rio de Janeiro's 2016 Olympic games must not proceed. Harvard Public Health Rev 2016 May. http://harvardpublichealthreview.org/off-the-podium-why-rios-2016olympic-games-must-not-proceed/.

2 Ministry of Health. Dengue, chikungunya and Zika. Boletim Epidemiológico 2016;47:18. Available at: http://portalsaude.saude.gov.br/images/pdf/2016/abril/27/2016-014-DengueSE13-substitui--o.pdf. (In Portuguese.)

3 Brooks M. Mosquitoes and Zika: time to harness genetic modification?BMJ 2016;353:i2548. doi:10.1136/bmj.i2548 pmid:27160110.

4 World Health Organization. WHO statement: Zika virus and the Olympic and Paralympic Games Rio 2016. 12 May 2016. www.who.int/mediacentre/news/statements/2016/zikaolympics/en/.

Published by the BMJ Publishing Group Limited. For permission to use (where not already granted under a licence) please go to http://group.bmj.com/group/rights-licensing/ permissions 